\title{
Impact of various surfactant classes on the microorganism community used for WWTP biodegradation treatment
}

https://doi.org/10.21698/rjeec.2020.226

Proceedings Paper

\author{
DANIEL MITRU ${ }^{1,3}$, IRINA LUCACIU $^{1}$, MIHAI NITA-LAZAR ${ }^{1}$, CRISTINA ILEANA \\ COVALIU $^{2}$, GHEORGHE NECHIFOR $^{3}$, IOANA CORINA MOGA ${ }^{4}$, BOGDAN MARIN $^{4}$, \\ IULIANA PAUN ${ }^{1,2 *}$
}

\author{
${ }^{I}$ National Research and Development Institute for Industrial Ecology-ECOIND, 71-73 Drumul Podu Dambovitei, \\ 060652, Sector 6, Bucharest, Romania \\ ${ }^{2}$ University Politehnica of Bucharest, Faculty of Biotechnical Systems Engineering, 313 Splaiul Independentei, 060042, \\ Bucharest, Romania \\ ${ }^{3}$ University Politehnica of Bucharest, Faculty of Applied Chemistry and Material Science, Department of Analytical \\ Chemistry and Environmental Engineering, 1-7 Polizu, 011061, Bucharest, Romania \\ ${ }^{4}$ DFR Systems SRL, 46 Drumul Taberei, 061392, Bucharest, Romania \\ *Corresponding author (e-mail): iuliana.paun@iincdecoind.ro
}

\begin{abstract}
Environmental pollution is an important issue influencing human health and environmental equilibrium. The range of pollutants is very wide due to industrialization and population growth and the surfactants are one of the most common organic pollutants due to their extensive use and ubiquitous presence from industry to households. Their massive presence in the domestic and industrial wastewater could affect the Wastewater treatment plants by inhibiting the activated sludge used in pollutants biodegradation treatment step. This paper aimed to study the inhibition effect of three classes of surfactants (nonionic, anionic, and cationic) by measuring the respiratory activity of microorganisms with the application of the Oxygen Uptake Rate (OUR) test. This study established that the surfactants could activate or inhibit microorganisms' activity, depending on surfactant concentration.
\end{abstract}

Keywords: activated sludge, inhibition effect, respirometry test, surfactants, wastewater treatment plants

\section{INTRODUCTION}

Surfactants are chemicals that are found in the composition of a large number of household cleaning detergents, personal care products, pesticides, and pharmaceuticals. Unfortunately, most of these compounds have been found in large amounts in the wastewaters, due to their overuse.

The surfactant molecule contains two structurally distinct parts, one of which is hydrophilic while the other is hydrophobic and they are classified in four classes, according to the nature of their hydrophilic parts: i) anionic surfactants, a surfactant in which the hydrophilic part carries a negative charge, such as alkyl sulphates, ii) cationic surfactants, a surfactant in which the hydrophilic part carries a positive charge, such as quaternary ammonium salts (benzalkonium chloride and bromide), iii) amphoteric surfactants a surfactant in which the hydrophilic part contains both positive and negative charges, such as alkylbetaines and iv) nonionic surfactants a surfactant in which the hydrophilic part is uncharged, such as ethoxylated fatty alcohols [1].

Anionic surfactants are the most used type worldwide, and they counting around $50 \%$ of the total type of surfactants used. They are can be used as detergents (alkyl-benzene sulfonates) (Fig.1), as foaming agents (lauryl sulfates), but also as soaps.

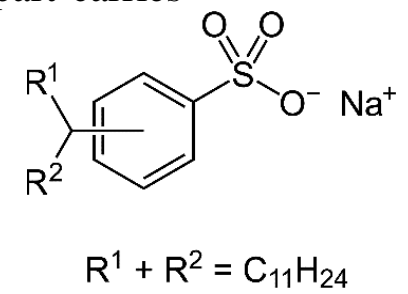

Fig. 1. Alky-benzene sulfonates structure 
Dodecane-1-sulfonic acid sodium salt, also known as sodium lauryl sulfonate or sodium 1dodecanesulfonate (molecular formula: $\mathrm{C}_{12} \mathrm{H}_{25} \mathrm{NaO}_{3} \mathrm{~S}$, molecular weight: $277.37 \mathrm{~g} / \mathrm{mol}$ ) is an anionic surfactant used as a flotation agent, foaming agent, penetrating agent, and emulsifiers.

Cationic surfactants are found as antistatic agents in fabric softeners and hair rinse formulas. Besides, there are used in textile manufacturing to delay dye adsorption. Benzalkonium chloride (Fig. 2) and alkyltrimethyl ammonium chloride or bromide are used as antiseptic agents, disinfectants, and sterilizing agents. They can also be incorporated as an additive in nonionic detergent formulation for corrosion inhibition purposes, and (in very small quantity) in anionic powdered formulas to synergize detergency [2].

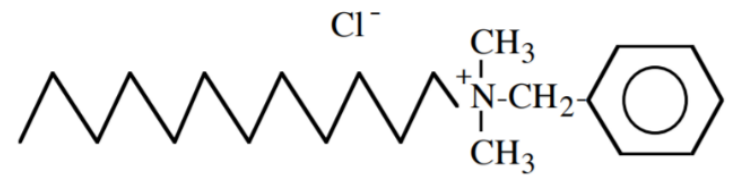

Fig. 2. Structure of benzalkonium chloride

Benzalkonium chloride is a mixture of n-alkyl benzyldimethyl ammonium chloride homologs, where $n$ represents an even number of carbons from $\mathrm{C} 8$ to $\mathrm{C} 18$. The most common homologs are $\mathrm{C} 12, \mathrm{C} 14$, and $\mathrm{C} 16$ [3], the biocidal properties of the individual homologs are known to be different [4].

Benzyldimethyltetradecylammonium chloride (molecular formula: $\mathrm{C}_{23} \mathrm{H}_{42} \mathrm{ClN}$, molecular weight: $368.04 \mathrm{~g} / \mathrm{mol}$ ) is a cationic surfactant used as a disinfectant and sanitizer and also as a wood preservative. It is added as a germicide to household wipe and towelette cleaners.
Nonylphenol polyethoxylates (NPnEOs, where $\mathrm{n}$ indicates the number of ethoxy units) (Fig. 3) are an important group of non-ionic surfactants that are widely used in many commercial and household functions, including detergents, cosmetic products, and textiles [5]. Nonionic surfactants do not dissociate in aqueous solutions. Moreover, they are used as emulsifier agents, in cosmetic products, but also as cleansing agents [6]. Thus, the most used type of nonionic surfactants is the polyethoxylated group due to their large field of utilization.<smiles>CCOc1ccc(OCCO)cc1</smiles>

Fig. 3. Structure of nonylphenol polyethoxylates

4-Nonylphenol polyethylene glycol ether (molecular

$\left(\mathrm{C}_{9} \mathrm{H}_{19} \mathrm{C}_{6} \mathrm{H}_{4}\left(\mathrm{OCH}_{2} \mathrm{CH}_{2}\right)_{9} \mathrm{OH}\right)$, formula: molecular weight: $616.82 \mathrm{~g} / \mathrm{mol}$ ) is a non-ionic surfactant with approx. 10 ethylene oxide units.

Overall, the surfactants present in the wastewater could impact on the Waste Water Treatment Plants (WWTP) treatment efficiency. At the present, WWTP decreases the pollution level mainly by two: one mechanical and the other one biological by biodegrading the pollutants with the help of microorganisms. A large amount of surfactants could disrupt the biological processes of microorganisms making inefficient the pollutants biodegradation step and therefore pollutants could reach the environment without being removed in the WWTP. Surfactant, in particular, could disrupt the microorganism's plasma membrane, which itself is made of a double layer of surfactants.

Due their utility and large wide utilization, linear alkylbenzenes are used as the main anionic surfactants in biodegradability processes because they are not particularly toxic at low concentrations [6]. Few measurements of surfactants in sewage effluents have been undertaken in the world. Several surfactants, linear alkylbenzene sulphonate (LAS), 
quaternary ammonia compounds (QAC), nonylphenolmono-( $\left.\mathrm{NP}_{1} \mathrm{EO}\right)$ and -diethoxylates $\left(\mathrm{NP}_{2} \mathrm{EO}\right)$, were monitored in treated and untreated sewage in nine municipal wastewater treatment plants (WWTPs) in western Austria. Total influent concentrations of LAS varied between $2.4 \mathrm{mg} / \mathrm{L}$ up to $6.7 \mathrm{mg} / \mathrm{L}$ whereas total effluent concentrations were in the range 7.9-50 $\mu \mathrm{g} / \mathrm{L}$. Benzalkonium chlorides (BACs) the $\mathrm{C} 12$ and the $\mathrm{C} 14$ homologs were measured in concentrations in influents of up to $170 \mu \mathrm{g} / \mathrm{L}$ of BAC-C12 and $110 \mu \mathrm{g} / \mathrm{L}$ of BAC-C14 and effluents of up to $0.5 \mu \mathrm{g} / \mathrm{L}$ of BAC-C12 and $0.63 \mu \mathrm{g} / \mathrm{L}$ of BAC-C14. Concentration of nonylphenolmono-( $\left.\mathrm{NP}_{1} \mathrm{EO}\right)$ and -diethoxylates $\left(\mathrm{NP}_{2} \mathrm{EO}\right)$ in effluent were measured in range $0.15-3.0 \mu \mathrm{g} / \mathrm{L}$ and $0.08-1.7 \mu \mathrm{g} / \mathrm{L}$ respectively, also in influent were measured in range 3.8-70 $\mu \mathrm{g} / \mathrm{L}$ and 2.3-11.6 $\mu \mathrm{g} / \mathrm{L}$ respectively [7].

Concentrations of linear alkylbenzene sulfonates in influent and effluent wastewaters from Seville (Southern Spain) ranged from 1155 to $9200 \mu \mathrm{g} / \mathrm{L}$, and from below the limit of detection to $770 \mu \mathrm{g} / \mathrm{L}$, respectively, whereas the concentrations of nonylphenol ethoxylates were significantly lower up on $0.65-0.67 \mu \mathrm{g} / \mathrm{L}$ and 0.18-0.25 $\mu \mathrm{g} / \mathrm{L}$, in industrial and urban wastewaters [8]. Also in Spain, in effluents, the concentrations of non-ionic surfactants ranged from 0.1 to $5 \mu \mathrm{g} / \mathrm{L}$, which reflects consistent elimination. Anionic surfactants were present in all waters studied at higher levels. Levels up to $3.9 \mathrm{mg} / \mathrm{L}$ of linear alkylbenzene sulfonates and $32 \mathrm{mg} / \mathrm{L}$ of alkyl ethoxysulfates (AESs) were detected in urban WWTP influents [9]. This quite large amount of surfactants in the influents of WWTPS can affect the WWTPs processes by adding an inhibitory effect on the activated sludge.

In Germany have monitoring campaign for effluent samples including 33 conventional wastewater treatment plants (WWTP) were analyzed for linear alkylbenzene sulfonates (LAS) and alkyl ethoxysulfates(AES). The average total LAS and AES effluent concentrations were still $14.4 \mu \mathrm{g} / \mathrm{L}$ and 0.57 $\mu \mathrm{g} / \mathrm{L}$, respectively. For the monitored WWTP effluents total LAS concentrations up on to 47.7 $\mu \mathrm{g} / \mathrm{L}[10]$.

The worldwide uses of surfactants in chemical industries such as household products, industrial cleaning, ink, pharmaceuticals, personal care, can affect the environment and human health [11]. In 2014 recorded 15.93 million tons of surfactants used and it is expected that in 2022 to be with over $1 / 3$ more (24.19 million tons of surfactants) [12].

Today, studies on the biodegradability of surfactants, the effect on the respiration of activated sludge or their chemical persistence are increasingly needed to show that products containing surfactants degrade in wastewater treatment plants before they reach the environment.

This study was performed to evaluate the effect of surfactants on the respiration of activated sludge collected from a municipal wastewater treatment plant (WWTP).

The effects on microorganisms of activated sludge were determined by measuring their respiration rate under defined conditions, in the presence of different concentrations of surfactants. The respiration rates of activated sludge fed with synthetic sewage were measured in cell containing an oxygen electrode: i) after a contact time of three hours every minute during about 10 minutes; ii) and every 15 minutes within 3 hours of sludge exposure to each type of surfactant.

Inhibition to activated sludge oxygen uptake rate (OUR) was carried out according to Romanian standard ISO 8192:2007 [13] and OCSPP 850.3000 guideline [14].

The purpose of this work was to develop a rapid screening method to identify the effect of surfactants on the treatment process with aerobic microorganisms and to establish concentrations that can be used in biodegradability tests.

\section{MATERIALS AND METHODS}

\section{Reagents}

The cationic surfactant (benzyl dimethyl tetradecyl ammonium chloride) and non-ionic surfactant (4-nonylphenol polyethylene glycol ether) were purchased from Sigma-Aldrich (Vienna, Austria) and anionic surfactant 
(dodecane-1-sulfonic acid sodium salt) was

Synthetic sewage and Microbial inoculum

A synthetic sewage feed is made by dissolving $16 \mathrm{~g}$ peptone, $11 \mathrm{~g}$ meat extract, $3 \mathrm{~g}$ urea, $0.7 \mathrm{~g}$ sodium chloride, $0.4 \mathrm{~g}$ calcium chloride dehydrate, $0.2 \mathrm{~g}$ magnesium sulfate heptahydrate, $2.8 \mathrm{~g}$ dipotassium hydrogen phosphate through in $1 \mathrm{~L}$ of water.

The sample of activated sludge was taken from the aeration basin of WWTP, the $\mathrm{pH}$ was at range 7.5 to 7.8 . After centrifuging the

\section{Methods for surfactants quantification}

Analyses of surfactant were performed using Specord BU 205 spectrophotometer (Analytic Jena, Germany).

Quantifications of anionic surfactant, a nonionic surfactant, and cationic surfactant were performed according to the standardizes methods. For the anionic surfactants was used the methylene blue active substance method standard EN 903:2003 [15], for the nonionic surfactants was used the method of bismuth active substance- standard ISO 7875-2:1996 [16] and for the cationic surfactants method used was with disulfide blue - DIN 38409:1989 [17].

For the quantification of anionic surfactants, a calibration curve based on a reference material was made. Methyl ester of dodecylbenzene sulfonic acid $\left(\mathrm{C}_{19} \mathrm{H}_{32} \mathrm{O}_{3} \mathrm{~S}\right)$ was the reference material and the calibration curve was made using six concentrations between $0 \mu \mathrm{g}$ to 420 $\mu \mathrm{g}$ with a detection limit of $0.05 \mathrm{mg} / \mathrm{L}$. The obtained from Merck (Darmstadt, Germany).

supernatant was decanted. This procedure was repeated three times. A small amount of the washed sludge was weighed and dried and was determined as $3 \mathrm{~g}$ suspended solids/L.

The synthetic sewage and the activated sludge sample (filtrated, washed with tap water and resuspended in tap water) were aerated until usage in the respirometric test.

linearity range standing from $21 \mu \mathrm{g}$ to $400 \mu \mathrm{g}$ (Fig. 4a).

Meanwhile, the MR for the nonionic surfactants used for the nonionic surfactants calibration curve was 4-nonylphenol polyethylene glycol ether $\left.\left(\mathrm{C}_{9} \mathrm{H}_{19} \mathrm{C}_{6} \mathrm{H}_{4}\left(\mathrm{OCH}_{2} \mathrm{CH}_{2}\right)_{9} \mathrm{OH}\right)\right)$ with linearity range between $200 \mu \mathrm{g}$ to $1000 \mu \mathrm{g}$ and a detection limit set at $0.05 \mathrm{mg} / \mathrm{L}$ (Fig. 4b).

For the quantification of cationic surfactants, a calibration curve with six standards of concentration was performed ranging from 0 $\mathrm{mg} / \mathrm{l}$ to $1 \mathrm{mg} / \mathrm{l}$ with a detection limit of 0.05 $\mathrm{mg} / \mathrm{L}$ and using as reference material: benzyl dimethyl tetradecyl ammonium chloride (Fig. $4 c)$.

Stock solutions of individual surfactants were prepared by dissolving precise amounts of pure standards in the water at a concentration of $1000 \mathrm{mg} / \mathrm{L}$, considering the purity of each surfactant. Concentrations of each stock solution were determined.

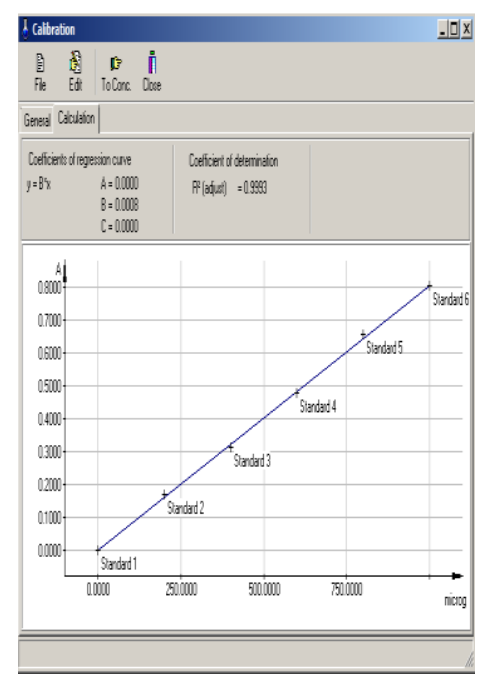

a)

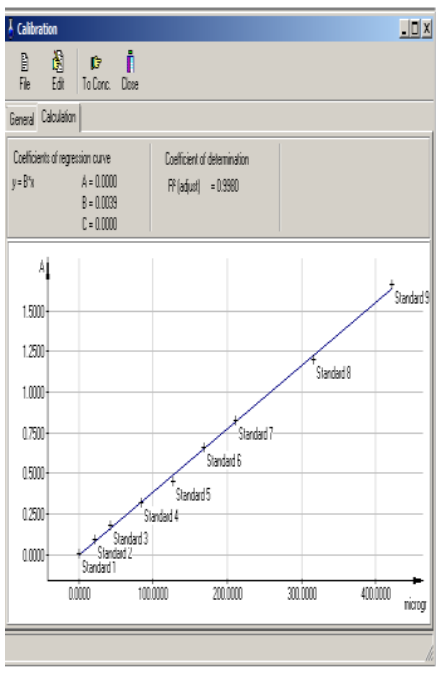

b)

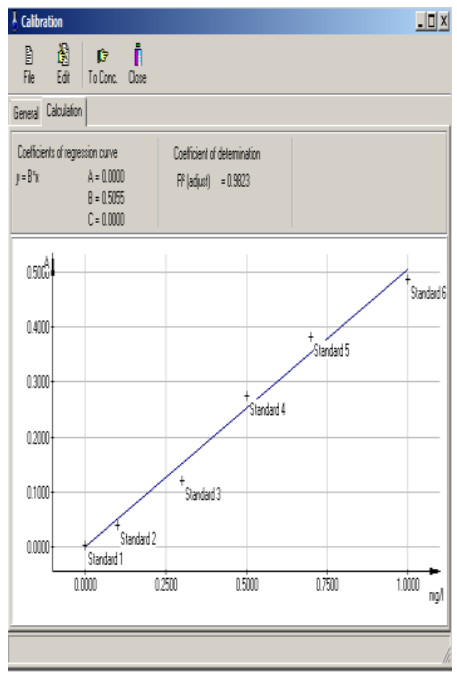

c)

Fig. 4. Calibration curve of a) anionic surfactants, b) non-ionic surfactant, c) cationic surfactant 


\section{Respiration experiments}

The respiration experiments were performed using: concentration of anionic surfactant, ranging from 4 to $70 \mathrm{mg} / \mathrm{L}$; concentration of non-ionic surfactant ranging from 1 to $25 \mathrm{mg} / \mathrm{L}$; concentration of cationic surfactant ranging from 1 to $10 \mathrm{mg} / \mathrm{L}$.

\section{i) Oxygen Uptake Rate (OUR) test experiment according standard ISO 8192:2007 [13]}

The concentrations of surfactants used in this experiment were:

- $4 \mathrm{mg} / \mathrm{L}, 20 \mathrm{mg} / \mathrm{L}, 40 \mathrm{mg} / \mathrm{L}$ and $70 \mathrm{mg} / \mathrm{L} \mathrm{-}$ dodecane-1-sulfonic acid sodium salt (anionic surfactant),

- $1 \mathrm{mg} / \mathrm{L}, 10 \mathrm{mg} / \mathrm{L}$ and $25 \mathrm{mg} / \mathrm{L}-4$ nonylphenol polyethylene glycol ether (nonionic surfactant).

All test concentrations and control samples were tested in three replicates. Test solutions and control samples were prepared by combining $16 \mathrm{~mL}$ synthetic sewage feed with different volumes of surfactant stock solution and water to a volume of $300 \mathrm{ml}$. All mixtures were aerated for some minutes to saturate the solutions with $\mathrm{O}_{2}$ above $60-70 \%$. Then, the test was started by adding suitable volumes of activated sludge suspension (microbial inoculum) giving a concentration of $1.5 \mathrm{~g}$ suspended solids/L in the test mixture and a total volume of $500 \mathrm{~mL}$.

After the addition of the inoculum, the flasks with test and control mixtures were closed and incubated for $3 \mathrm{~h}$ at approximately $20^{\circ} \mathrm{C}$, with agitation, but without aeration. After the incubation period, a sample of each mixture was poured into a measuring flask and stirred vigorously on a magnetic stirrer. An oxygen electrode (WTW Model 3430) was inserted into the sample and the oxygen concentration $(\mathrm{mg} / \mathrm{L})$ was continuously measured every minute for about $10 \mathrm{~min}$. Concentrations of surfactant initial and after $3 \mathrm{~h}$ was determined.

The OUR was expressed as the decrease in dissolved oxygen content $\left(\mathrm{mg} \mathrm{O}_{2}\right)$ per time unit (h):

$$
\text { OUR }=\frac{\text { initial oxygen concentration-final oxygen concentration }}{\Delta t}, \mathrm{mg} \mathrm{O} / \mathrm{L} \cdot \mathrm{h}
$$

where initial oxygen concentration and final oxygen concentration are express in $\mathrm{mg} \mathrm{O}_{2} / \mathrm{L}$

The respiration rate $\left(\mathrm{mg} \mathrm{O}_{2}\right.$ per $\mathrm{g}$ dry weight active sludge per hour) was calculated by linear regression of the oxygen concentration readings in the linear part of the oxygen depletion curve.

$$
\% I N H=\frac{O U R_{0}-O U R_{\text {surf }}}{O U R_{0}} * 100
$$

where $O U R_{0}$ is dissolved oxygen content for the control sample $(\mathrm{mg} \mathrm{O} / \mathrm{L} \cdot \mathrm{h})$ and $O U R_{\text {surf }}$ is

The amount of oxygen consumed by activated sludge in presence of analyzed surfactant was compared with the consumption of the control and $\Delta t$ represents time in $\mathrm{h}$.

The percentage inhibition of the respiratory activity is expressed as the percentage reduction OUR values relative to the control and determined by the formula:

dissolved oxygen content for surfactant solution ( $\left.\mathrm{mg} \mathrm{O}_{2} / \mathrm{L} \cdot \mathrm{h}\right)$.

sample (activated sludge with synthetic sewage without surfactant).

\section{ii) Experiment according OCSPP 850.3000 guideline [14]}

After the addition of the inoculum, the flasks with test and control mixtures were closed and incubated

were closed and incubated at approximately $20^{\circ} \mathrm{C}$, with agitation, but without aeration and the oxygen concentration $\left(\mathrm{mgO}_{2} / \mathrm{L}\right)$ was measured every $15 \mathrm{~min}$ for $3 \mathrm{~h}$.

The same 3-h OUR test experiment was performed for all types of surfactants, using the following concentrations: 
- $4 \mathrm{mg} / \mathrm{L}, 20 \mathrm{mg} / \mathrm{L}$ - dodecane-1-sulfonic acid sodium salt (anionic surfactant),

- $10 \mathrm{mg} / \mathrm{L}$ and $25 \mathrm{mg} / \mathrm{L}$ - 4-nonylphenol polyethylene glycol ether (non-ionic surfactant), - $1 \mathrm{mg} / \mathrm{L}$ and $10 \mathrm{mg} / \mathrm{L}$ - benzyl dimethyl tetradecyl ammonium chloride (cationic surfactant).

\section{RESULTS AND DISCUSSION}

The first phase of this study involved verification of the inhibitory effect of 3 different types of surfactants on activated sludge with the application of the Oxygen Uptake Rate (OUR) test.

3 series of oxygen uptake measurements were performed for anionic surfactant solution with different concentrations (range: 4 to $70 \mathrm{mg} / \mathrm{L}$ ). After $3 \mathrm{~h}$ incubation, the oxygen concentration (average of 3 replicates/surfactant concentration or control sample) was recorded every minute for about $10 \mathrm{~min}$ for each tested surfactant concentration and also, control sample.

Meanwhile, also the effect of non-ionic surfactants on activated sludge was evaluated by measuring oxygen uptake for test solution at different concentrations (from 1 to $25 \mathrm{mg} / \mathrm{L}$ ).

The same incubation period $(3 \mathrm{~h})$ and the same process of incubation were applied to the
During the experiment samples from surfactant solutions were taken at regular intervals (after each hour). After collection, the samples were centrifuged and in supernatants, the concentrations of anionic, non-ionic, and cationic surfactants were determined.

anionic surfactants as the nonionic surfactants, too.

After $3 \mathrm{~h}$ incubation, the oxygen concentration (average of 3 replicates/surfactant concentration or control sample) was recorded every minute for about $10 \mathrm{~min}$ for each tested surfactant concentration and also, control sample.

The results obtained for anionic and nonionic surfactants are presented as respirograms (Fig. 5-6).

The respiration rates (OURs) were calculated by linear regression of oxygen concentration readings during the linear part of the curves $\left(\mathrm{O}_{2}\right.$-depletion).

OURs after $3 \mathrm{~h}$ and the degree of inhibition of the respiratory activity of sludge $(\% \mathrm{INH})$ for each test solutions are summarized in Table 1 for the anionic surfactant and respectively Table 2 for the nonionic surfactant.

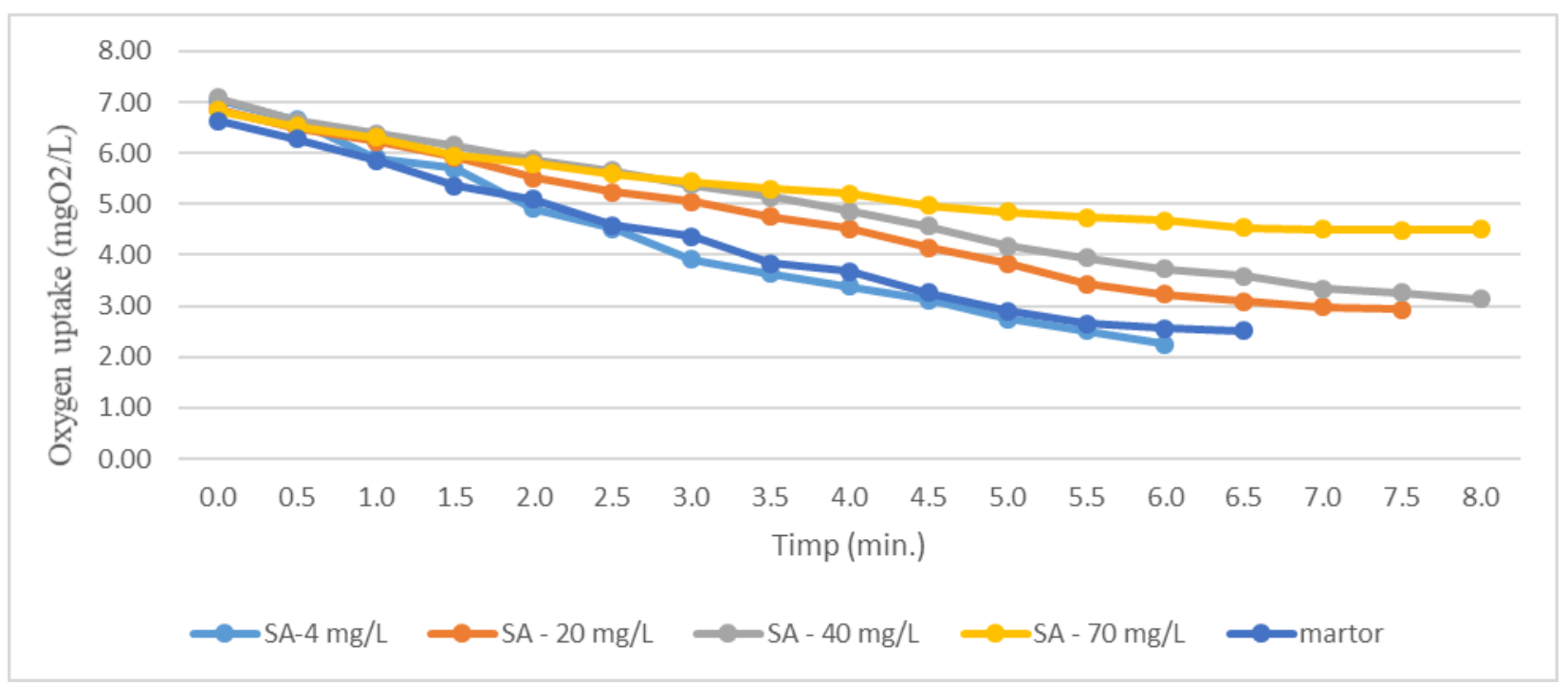

Fig. 5. Respirograms for activated sludge with anionic surfactant 
D. Mitru et. al.: Impact of various surfactant classes on the microorganism community used for WWTP biodegradation treatment

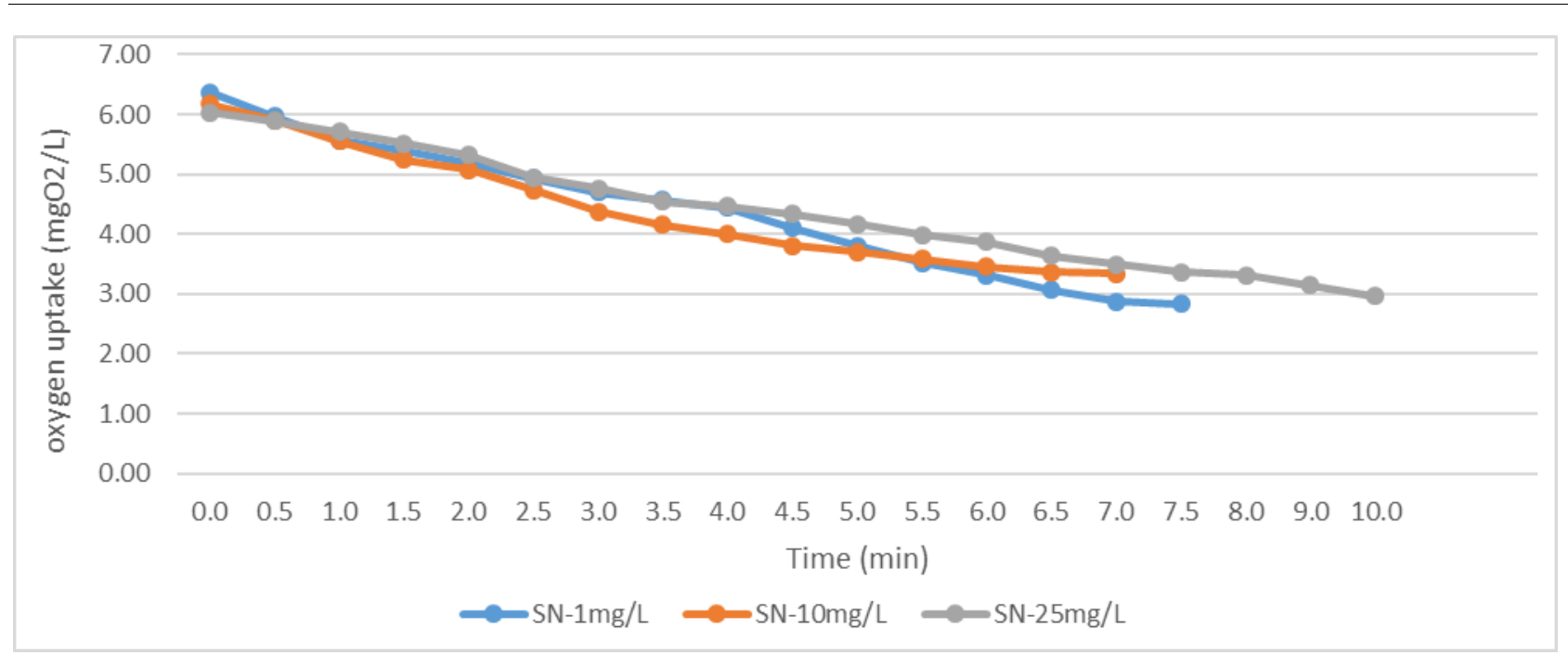

Fig. 6. Respirograms for activated sludge non-ionic surfactant

Table 1. OUR and degree of inhibition (\%) for the anionic surfactant and control sample

\begin{tabular}{|c|c|c|c|c|c|}
\hline \multirow[t]{2}{*}{ OUR } & \multicolumn{4}{|c|}{ Anionic Surfactant concentration } & Control sample \\
\hline & $4 \mathrm{mg} / \mathrm{L}$ & $20 \mathrm{mg} / \mathrm{L}$ & $40 \mathrm{mg} / \mathrm{L}$ & $70 \mathrm{mg} / \mathrm{L}$ & \\
\hline $\mathrm{mgO}_{2} /(\mathrm{L} \cdot \mathrm{h})$ & 47.25 & 33.26 & 28.80 & 17.55 & 43.40 \\
\hline $\mathrm{mgO}_{2} /(\mathrm{g} \cdot \mathrm{h})$ & 31.50 & 22.20 & 19.20 & 11.70 & 29.00 \\
\hline$\% \mathrm{INH}$ & -0.09 & 23.40 & 33.60 & 59.60 & \\
\hline
\end{tabular}

Table 2. OUR and degree of inhibition (\%) for the nonionic surfactant and control sample

\begin{tabular}{c|ccc|c}
\hline \multirow{2}{*}{ OUR } & \multicolumn{3}{|c|}{ Nonionic } & \multicolumn{3}{|c}{ Surfactant concentration } & \multirow{2}{*}{ Control sample } \\
& $1 \mathrm{mg} / \mathrm{L}$ & $10 \mathrm{mg} / \mathrm{L}$ & $25 \mathrm{mg} / \mathrm{L}$ & \\
\hline $\mathrm{mgO}_{2} /(\mathrm{L} \cdot \mathrm{h})$ & 28.62 & 27.30 & 19.30 & 30.00 \\
$\mathrm{mgO}_{2} /(\mathrm{g} \cdot \mathrm{h})$ & 19.00 & 18.20 & 12.80 & 20.00 \\
$\%$ INH & 4.70 & 9.00 & 37.00 & \\
\hline
\end{tabular}

Validity criteria of the standard method were fulfilled, as follows:

- the mean oxygen uptake rate of the control sample (without surfactant) was determined to be $29 \mathrm{mg} \mathrm{O}_{2} /(\mathrm{g} \cdot \mathrm{h})$ for anionic surfactants and $20 \mathrm{mg} \mathrm{O} /(\mathrm{g} \cdot \mathrm{h})$ for nonionic surfactant dry matter after $3 \mathrm{~h}$ experiment, which is well above the recommended lower limit of $20 \mathrm{mg} \mathrm{O}_{2}$ per $\mathrm{g}$ of activated sludge in an hour;

- the mean oxygen uptake rate in control replicates for anionic surfactants was $43.4 \mathrm{mg}$ $\mathrm{O}_{2} /(\mathrm{L} \cdot \mathrm{h})$, the standard deviation was $1.42 \mathrm{mg}$ $\mathrm{O}_{2} /(\mathrm{L} \cdot \mathrm{h})$, corresponding to a coefficient of variation of $3.3 \%$, which is far below the recommended upper limit of $30 \%$;

- the mean oxygen uptake rate in control replicates for nonionic surfactants was $30 \mathrm{mg}$ $\mathrm{O}_{2} /(\mathrm{L} \cdot \mathrm{h})$, the standard deviation was $1.21 \mathrm{mg}$ $\mathrm{O}_{2} /(\mathrm{L} \cdot \mathrm{h})$, correlating to a coefficient of variation of $4.02 \%$, which is below the recommended upper limit of $30 \%$.

The effect of surfactant on the respiration rate of activated sludge can be expressed as an $\mathrm{EC}_{50}$ value, the concentration that reduces the respiration rate by $50 \%$.

To estimate the $\mathrm{EC}_{50}$ value (mean inhibitory concentration on activated sludge microorganisms), the inhibition percentages were plotted against surfactant concentrations (Fig.7-8). The data shown in Figure 7 allowed the estimation of $\mathrm{EC}_{20}$ value (20\% inhibition) for anionic surfactant (dodecane-1-sulfonic acid sodium salt) of $16-17 \mathrm{mg} / \mathrm{L}$ and $\mathrm{EC}_{50}$ value (50\% inhibition) of approximate $55-56 \mathrm{mg} / \mathrm{L}$. Accordingly, concentrations of anionic surfactant higher than $15 \mathrm{mg} / \mathrm{L}$ can affect the respiration of activated sludge and consequently can disrupt the biological treatment process in municipal WWTPs from Romania. 


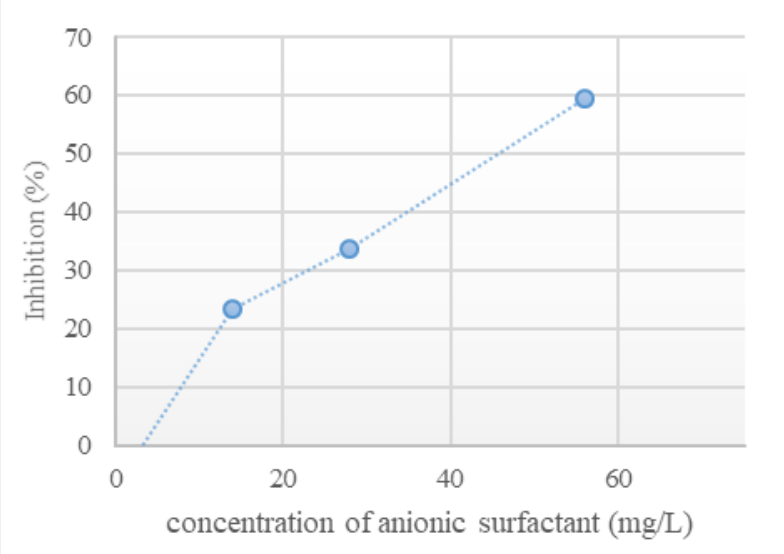

Fig. 7. Anionic surfactant effect on activated sludge after $3 \mathrm{~h}$

Similar studies published in the literature indicate inhibitory effects on activated sludge oxygen uptake rate, which increased from 12.9 to $44.2 \%$ for sodium dodecyl sulfate (SDS) [18]. However, sodium dodecyl benzene sulphonate (SDBS) inhibition was more severe than that incurred by SDS, ranging from 27.6 to $75.5 \%$ for 10 to $100 \mathrm{mg} / \mathrm{L}$. Besides, another study published in Poland highlights that other type of anionic surfactant (Linear Alkylbenzene Sulfonate-LAS) tested in a respirometry process did not reach to $\mathrm{EC}_{50}$ even if the stock concentration was $200 \mathrm{mg} / \mathrm{L}$ [19]. Inhibition of anionic surfactants to activated sludge can be attributed to the different types of structure, which means different toxic levels.

Also, biocenosis of activated sludge and operating conditions in the WWTP can play an important role in controlling the response of

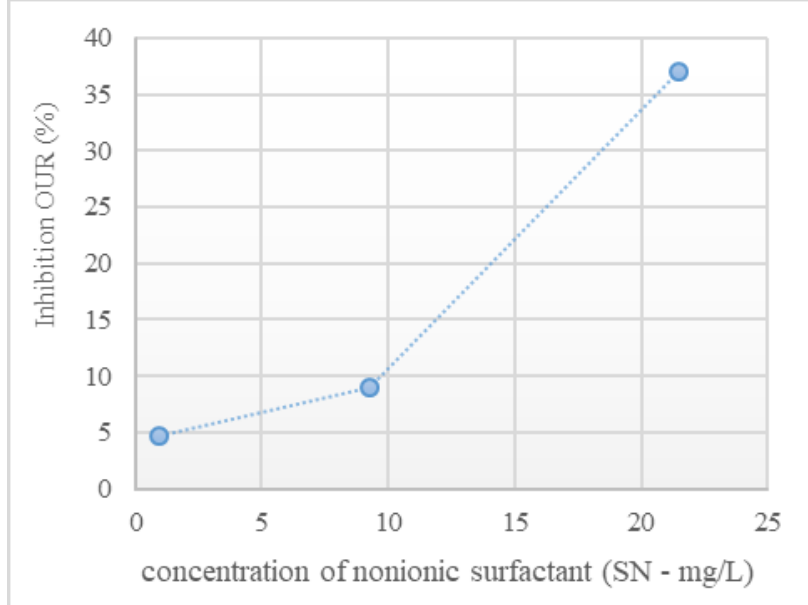

Fig. 8. Nonionic surfactant effect on activated sludge after $3 \mathrm{~h}$

activated sludge microorganisms to surfactant inhibiting. The nonionic surfactant (4nonylphenol polyethylene glycol ether) inhibitory effect on the respiration rate of activated sludge did not allow the estimation of an EC50 value, the inhibition being below 50\% for all tested concentrations. As is shown in Figure 8 nonionic surfactant inhibition ranged from $5 \%$ at $1 \mathrm{mg} / \mathrm{L}$ to almost $40 \%$ at $25 \mathrm{mg} / \mathrm{L}$.

A similar study [18] shows the effect of nonionic surfactants (Tergitol NP type) on activated sludge OUR - inhibition ranged from $5.5-27 \%$ at $1 \mathrm{mg} / \mathrm{L}$ to $15-60 \%$ at $100 \mathrm{mg} / \mathrm{L}$.

In the second phase of this study, the removal efficiency of anionic surfactants increases with times, from 40 to $53 \%$ for $\mathrm{C} 1(4 \mathrm{mg} / \mathrm{L})$ and from 56 to $69 \%$ for $\mathrm{C} 2(20 \mathrm{mg} / \mathrm{L})$ showing in the Figure 9a.

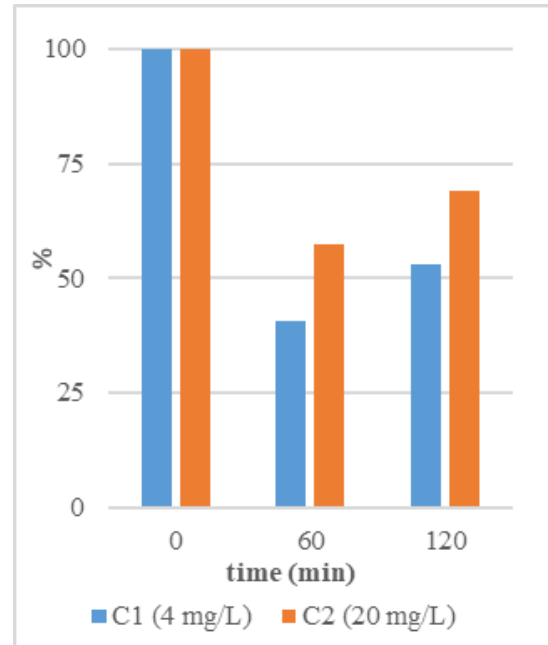

a)

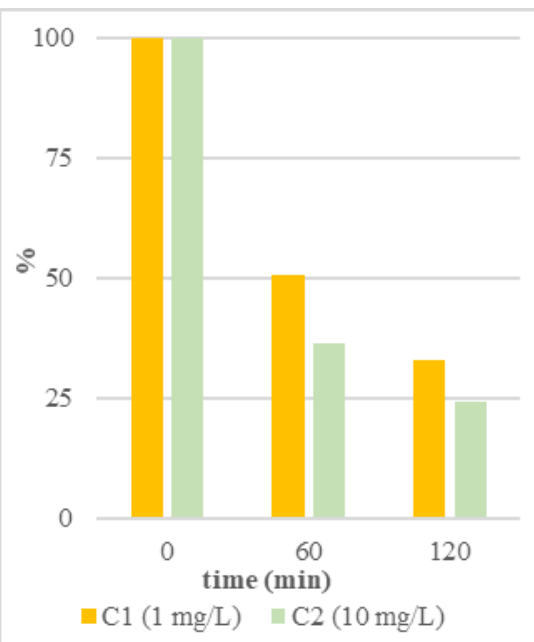

b)

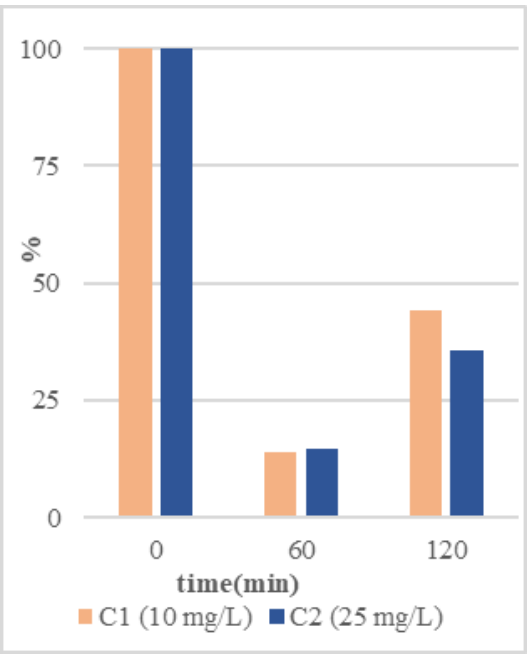

c)

Fig. 9. The removal efficiency of a) anionic surfactant, b) cationic surfactant, and c) non-ionic surfactant 
After $3 \mathrm{~h}$ the removal rate is $80 \%$ for both concentrations, but these results are not reported because the wastewater in the biological stage lasts a minimum of two hours. This percentage of removal can be attributed to the adsorption of surfactants on the activated sludge, do due to the electric charge interaction of anionic surfactants with the activated sludge chemical compounds. The important decrease of anionic surfactant concentration ca be assigned also to the linear structure of dodecane-1-sulfonic acid sodium salt because they can be removed easily from the environment.

As shown in Figure 9b, the cationic surfactant removal efficiency decreases with times, from 50 to $35 \%$ for $\mathrm{C} 1(1 \mathrm{mg} / \mathrm{L})$ and from 33 to $24 \%$ for $\mathrm{C} 2(10 \mathrm{mg} / \mathrm{L})$. After $3 \mathrm{~h}$ removal rate increases, which may be related to the fact that they have a very long structure chain and their reduction is harder than the other types of surfactants. This situation can be attributed to the adsorption of cationic surfactants on activated sludge, due to the stronger interaction of electric charge with the chemical compounds of activated sludge.
The non-ionic surfactant removal efficiency as can be seen in Figure 9c is after-hours below $50 \%$ for both concentrations and these values are maintained after three hours. This situation can be placed on the fact that non-ionic surfactants are no possessing an electric charge and the interaction with the activated sludge is much lower compared with the anionic surfactants and also can be correlated to the persistence of polyethoxylated compounds in the environment.

The results showed that microbial respiration inhibition was modulated by surfactants and the degree of inhibition was time-dependent. The anionic surfactant, dodecane-1-sulfonic acid sodium salt, induced inhibition of respiration direct proportionally with the concentrations from $15 \%$ inhibition at $\mathrm{C} 1(4 \mathrm{mg} / \mathrm{L})$ to $26 \%$ inhibition at $\mathrm{C} 2(20 \mathrm{mg} / \mathrm{L})$ after $60 \mathrm{~min}$ of incubation (Fig. 10). Furthermore, a longer incubation time increased the inhibition from $15 \%$ for $\mathrm{C} 1$ at $60 \mathrm{~min}$ to $44 \%$ inhibition after $120 \mathrm{~min}$. The same inhibition pattern was observed for $\mathrm{C} 2$ surfactant concentration during the time.

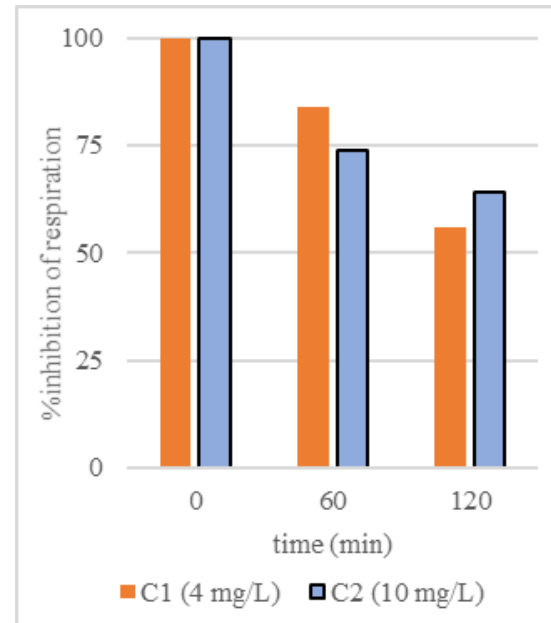

a)

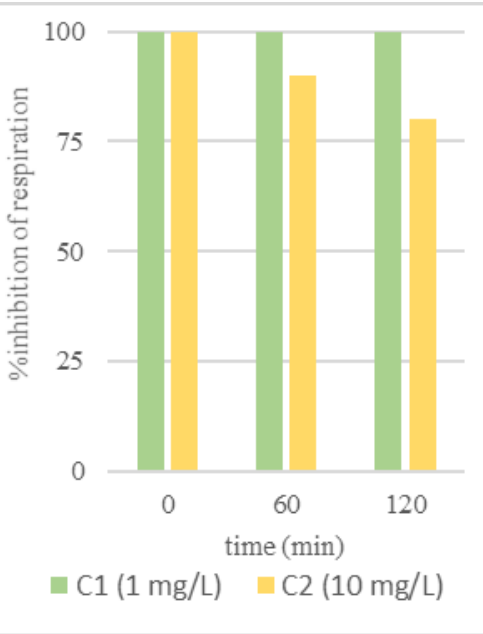

b)

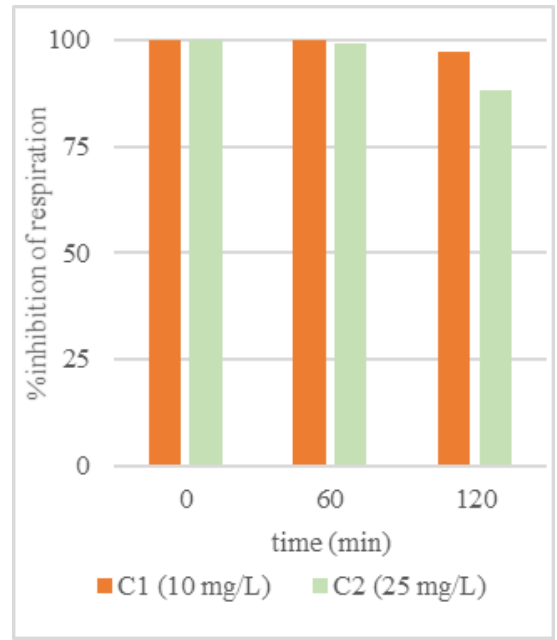

c)

Fig. 10. Microbial respiration inhibition by a) anionic surfactant, b) cationic surfactant and c) nonionic surfactant

The results were compared to the control samples, microbial incubation without surfactant. The non-ionic surfactant, 4-nonylphenol polyethylene glycol ether, had a little inhibition effect on the microbial respiration even at 25 $\mathrm{mg} / \mathrm{L}$, decreasing the respiration by $12 \%$ after 120 min of incubation time (Fig. 6). At a concentration $\mathrm{C} 1 \quad(10 \mathrm{mg} / \mathrm{L})$, the non-ionic surfactant had no significant effect on the microbial respiration. On the opposite, the cationic surfactant, benzyl dimethyl tetradecyl ammonium chloride, had a strong inhibition effect of respiration at $10 \mathrm{mg} / \mathrm{L}$, reaching up to $20 \%$ inhibition (Fig. 10).

Overall, anionic surfactant seemed to induce the highest inhibition rate of microbial respiration followed by the cationic and the non-ionic surfactant. 


\section{CONCLUSIONS}

Synthetic surfactants are used as principal constituents of commercial detergents therefore, significant amounts of surfactants $(10-20 \mathrm{mg} / \mathrm{L})$ can reach municipal WWTPs. Even though anionic surfactants are reasonably aerobically degradable and not particularly toxic at low concentrations, high concentrations of these surfactants could be harmful to the environment. The negative impact of high concentrations of anionic/nonionic surfactants on activated sludge metabolism was confirmed by respirometric measurements.

The surfactants have an effect on the microbial community from the activated sludge involved in the wastewater treatment procedure. Inhibition of the microbial respiration process is an important sign of the surfactant pollution degree which could decrease the WWTP efficiency.

The present study revealed a negative impact/inhibitory effect of anionic surfactant (dodecane-1-sulfonic acid sodium salt) and nonionic surfactant (4-Nonylphenol polyethylene glycol ether) on activated sludge. The respiratory activity of activated sludge bacteria was inhibited at anionic surfactant (dodecane-1sulfonic acid sodium salt) loads greater than 20 $\mathrm{mg} / \mathrm{g}$ activated sludge, while was not inhibited at non-ionic surfactant for all tested concentrations.

Surfactant content in typical municipal sewage usually does not exceed $15 \mathrm{mg} / \mathrm{L}$, which allows us to appreciate that the biological treatment process with activated sludge cannot be

\section{ACKNOWLEDGEMENTS}

This work was supported by a grant of the Romanian Ministry of Education and Research

\section{REFERENCES}

[1] CULLUM, D.C., Surfactant types: classification, identification, separation. Introduction to Surfactant Analysis, Springer, Dordrecht, 1994, p.17-41.

[2] SALAGER, D.J., Surfactants: Types and Uses, Universidad de Los Andes, MéridaVenezuela, Version 2, 2002, p. 39.

[3] HALVAX, J.J., WIESE, G., ARP, J.A., VAN BENNEKOM, M.P., BULT, A., J. Pharm. Biomed. Anal., 19, no. 6, 1999, p. 877.

[4] GOMEZ-GOMAR, A., GONZALEZ- negatively affected by surfactant concentrations from the influent of WWTP.

In the range of concentrations $1-10 \mathrm{mg} / \mathrm{L}$ the inhibition on the rate of oxygen consumption of activated sludge is insignificant (below 10\%) and at concentrations higher than $15-20 \mathrm{mg} / \mathrm{L}$ there are inhibitory effects of $22-37 \%$.

Anionic surfactant concentration not exceeding 4-5 $\mathrm{mg} / \mathrm{L}$ and non-ionic surfactant concentration not exceeding $10 \mathrm{mg} / \mathrm{L}$ have no negative influence on the respiratory process of activated sludge, moreover, it can improve the biological activity of the sludge (OUR greater than the value obtained for the control sample).

The presence of surfactants at high loads in sludge may enhance negative biochemical processes, such as decreasing microorganism's respiration and disruption of the entire biological treatment process.

The values obtained for the degree of inhibition of anionic and nonionic surfactants on the respiratory activity of sludge in the two experiments are comparable.

In the experiments in which using the cationic surfactant, was observed that the values of removal yields are high compared to those obtained for anionic surfactants and nonionic surfactants, which may mean that they are more adsorbed on the sludge.

In the future, adsorption/desorption tests of surfactants will be performed, especially of cationic surfactants from biological sludge samples to establish the ratio between adsorption and biodegradation.

CCDI-UEFISCDI

(PN-III-P2-2.1-PTE-20190628 - PNCDI III).

AUBERT, M.M., GARCES-TORRENTS, J., COSTA SEGARRA, J., J. Pharm. Biomed. Anal, 8, no.8-12, 1990, p 871.

[5] BIRKETT, J.W., LESTER, J.N., Endocrine Disrupters in Wastewater and Sludge Treatment Processes. CRC Press LLC, Florida, 2003, p. 1-312.

[6] DERESZEWSKA, A., CYTAWA, S., MEDRZYCKA, K., Pol. J. Environ. Stud., 24, no. 1,2015, p.83.

[7] CLARA, M., SCHARF, S., 
SCHEFFKNECHT, C., GANS, O., Water Res., 41, no.19, 2007, p. 4339.

[8] CAMACHO-MUNOZ, D., MARTIN, J., SANTOS, J.L., APARICIO, I., ALONSO E., Sci. Total Environ., 468-469, 2014, p. 977.

[9] GOMEZ V., FERRERES E., POCURULL E., BORRUL F., Talanta, 84, no. 3, 2011, p. 859.

[10] FREELING, F., ALYGIZAKIS, N.A., VON DER OHE, P.C., SLOBODNIK, J.A., OSWALD, P., ALIZADEH, R.A., CIRKA, L., THOMAIDIS, N.S., SCHEURER, M., Sci. Total Environ., 681, 2019, p. 475.

[11] LE GUENIC, S., CHAVERIAT, L., LEQUART, V., JOLY, N., MARTIN, P. J., Surfactants Deterg., 22, no. 1, 2019, p. 5.

[12] PALMER M., HATLEY H., Water Res., 147, no. 15,2018 , p. 60 .

[13] ISO 8192:2007, Water quality - Test for inhibition of oxygen consumption by activated sludge for carbonaceous and ammonium oxidation.

[14] EPA 712-C-014:2012, Ecological Effects Test Guidelines OCSPP 850.3300: Modified Activated Sludge, Respiration Inhibition Test.

[15] EN 903:2003, Water quality Determination of surfactants - Part 1: Determination of anionic surfactants by measurement of the methylene blue index (MBAS).

[16] ISO 7875-2:1984, Water quality Determination of surfactants - Part 2: Determination of non-ionic surfactants using Dragendorff reagent.

[17] DIN 38 409:1981 Teil 20, The method for the determination of cationic surfactants with the disulfine blue method (DBAS).

[18] OTHMAN, M.Z., DING, L., JIAO, Y., International Journal of Chemical and Molecular Engineering, 3, no.10, 2009, p. 596. [19] DERESZEWSKA, A., CYTAWA, S., Joint Proceedings, 23, 2010, p. 35. 